\title{
PRAKTIK PENGALAMAN LAPANGAN BERBASIS KOLABORATIF ANTARA MAHASISWA DENGAN GURU PAMONG DI MTSN KABUPATEN GOWA
}

\author{
Usman, Muh. Sain Hanafy, Bahraeni \\ Fakultas Tarbiyah dan Keguruan Universitas Islam Negeri Alauddin Makassar \\ E-mail: usman.tarbiyah@uin-alauddin.ac.id,muh.sainhanafy@uin-alauddin.ac.id, \\ bahraeni.tarbiyah@uin-alauddin.ac.id
}

\begin{abstract}
The practice of collaborative based field experience between students and tutor teachers at MTSN 1 in Gowa Regency is one of the authors' research results in 2018. This paper is devoted to reviewing the response of students of Islamic Education Department of Tarbiyah and Teacher Training UIN Alauddin Makassar and tutor teachers where they implement collaborative PPL (at MTsN Gowa Regency). The data sources in this study were 18 students (through 3 PPL groups) and 3 tutors. This study describes 3 things: (1) the implementation of Collaborative-based Field Experience Practices between Students and Teachers; (2) student responses to the implementation of collaborative practice based on field experience between tutors and students; and (3) Pamong teacher's response to the implementation of collaborative practice based on field experience between tutor teachers and students.

The results of the study show that: (1) the implementation of Collaborativebased Field Experience Practices between Students and Teachers in Gowa District MTsN has proceeded according to the procedures for implementing activities through stages: (a) registration and selection through faculty academics; (b) student debriefing activities; (c) workshop for tutors and tutors; (d) release and delivery of PPL students; (e) school observation and program planning; $(f)$ teaching guided patterns 75:25; ( $h$ ) FGD 1; ( $i$ ) implementation of guided learning pattern 50:50; (j) FGD 2; ( $k$ ) independent teaching; (l) FGD 3; $(m)$ practice exam; (n) student withdrawal; and (o) preparation of reports; (2) student responses to the implementation of collaborative-based field experience practices are included in the positive category, namely the average value of 2.99 (good); (3) the response of tutor teachers to the implementation of collaborativebased field experience practices is included in the positive category, namely the average value of 3.04 (good).
\end{abstract}

Keywords: Collaborative PPL, Students, Tutor Teachers.

\section{PENDAHULUAN}

\section{A. Latar Belakang}

$\mathrm{F}$ lakultas Tarbiyah dan Keguruan UIN Alauddin Makassar sebagai lembaga penyelenggara pendidikan dan tenaga kependidikan diharapkan mencetak sarjana/alumni yang memiliki kualifikasi calon pendidik dan tenaga kependidikan, baik pada madrasah maupun pada sekolah, sehingga perlu terhadap jaminan mutu 
lulusannya. Sebagai upaya perbaikan mutu, mulai tahun 2017 dilakukan PPL kolaboratif antara mahasiswa dengan guru pamong. Hali ini mengadopsi teori pembelajaran sosial yang merupakan perluasan dari teori belajar perilaku yang tradisional (behavioristik). Teori pembelajaran sosial ini dikembangkan oleh Albert Bandura (1999). Teori ini menekankan bahwa lingkungan yang dihadapkan pada seseorang secara kebetulan, lingkungan-lingkungan itu kerap kali dipilih dan diubah oleh orang itu melalui perilakunya sendiri. Menurut Bandura, sebagaimana dikutip oleh (Kardi dan Nur M, 2000: 14) bahwa sebagian besar manusia belajar melalui pengamatan secara selektif dan mengingat tingkah laku orang lain. Inti dari pembelajaran sosial adalah pemodelan (modelling), dan pemodelan ini merupakan salah satu langkah paling penting dalam kegiatan pembelajaran.

Ada dua jenis pembelajaran melalui pengamatan, yaitu: (1) pembelajaran melalui pengamatan dapat terjadi melalui kondisi yang dialami orang lain, Contohnya seorang pelajar melihat temannya dipuji dan ditegur oleh gurunya karena perbuatannya, maka dia kemudian meniru melakukan perbuatan lain yang tujuannya sama ingin dipuji oleh gurunya. Kejadian ini merupakan contoh dari penguatan melalui pujian yang dialami orang lain; (2) pembelajaran melalui pengamatan meniru perilaku model meskipun model itu tidak mendapatkan penguatan positif atau penguatan negatif saat mengamati itu sedang memperhatikan model itu mendemonstrasikan sesuatu yang ingin dipelajari oleh pengamat tersebut dan mengharapkan mendapat pujian atau penguatan apabila menguasai secara tuntas apa yang dipelajari itu. Model tidak harus diperagakan oleh seseorang secara langsung, tetapi kita dapat juga menggunakan seseorang pemeran atau visualisasi tiruan sebagai model (Nur, 1998: 4).

Di samping teori Bandura, model PPL kolaboratif juga mengadopsi teori Dewey tentang pendidikan adalah, yakni "... pembentukan kembali arau pengorganisasian ulang pengalaman yang menambah maknanya dan yang menambah kemampuan si pelajar dalam memberi arah terhadap pengalaman yang selajutnya. Untuk mencapai maksud tersebut, guru memiliki peranan penting untuk membimbing pelajar memperluas pengetahuan dan kemampuan berpikirnya dalam menjelajah hubungan baru yang dibangunnya di atas pengetahuan yang dimiliki sebelumnya.

Praktik Pengalaman Lapangan (PPL) berbasis kolaboratif antara mahasiswa dengan guru pamong pada dasarnya dapat dilakukan dalam bentuk: petama, guru pamong mengajar mahasiswa PPL mencatat seluruh aktivitas pembelajaran (100\% peran guru pamong); kedua, guru pamong mengajar mahasiswa PPL membantu guru pamong mendistribusi logistik pembelajaran ( $75 \%$ peran guru pamong dan $25 \%$ peran mahasiswa); ketiga, guru pamong mengajar dan mahasiswa PPL mengajar (50\% peran guru pamong dan $50 \%$ peran mahasiswa); keempat, mahasiswa PPL mengajar dan guru pamong membantu mahasiswa membagi logistic pembelajaran (75\% peran mahasiswa PPL dan guru pamong 25\%); kelima, mahasiswa melakukan pembelajaran mandiri (guru pamong mengamati aktivitas pembelajaran dan dosen pembimbing ikut proses pengamatan) yang dilanjutkan dengan FGD dalam rangka refleksi (Tim Penyusun Panduan PPL, 2017). 
Sebelum tahun 2017, Fakultas Tarbiyah dan Keguruan UIN Alauddin Makassar menerapakan PPL 100\% mahasiswa belajar mengajar mandiri. Perubahan ini dimaksudkan untuk meminimalisir kerugian yang dimiliki peserta didik jika dia diajar oleh bukan guru sesungguhnya, tetapi baru sebatas calon guru. Dengan melihat pola perubahan pelaksanaan PPL sebagaimana digambarkan di atas, maka dipandang perlu diketahui dalam bentuk respon bagi seluruh komponen yang terlibat dalam kegiatan PPL. Upaya mengetahuinya tentu melalui kegiatan penelitian, yang diharapkan mampu mendeskripsikan secara rasional, empirik dan sistematis mengenai pelaksanaan PPL berbasis kolaboratif dengan permasalahan: (1) Bagaimana pelaksanaan prakik pengalaman lapangan berbasis kolaboratif antara mahasiswa dengan guru pamong di MTsN 1 Kabupaten Gowa? (2) Bagaimana respon mahasiswa terhadap pelaksanaan prakik pengalaman lapangan berbasis kolaboratif di MTsN 1 Kabupaten Gowa? dan (3) Bagaimana respon guru pamong terhadap pelaksanaan prakik pengalaman lapangan berbasis kolaboratif di MTsN 1 Kabupaten Gowa?

\section{B. Kajian Teoretis}

1. Teori Respon

Respon atau tanggapan adalah kesan-kesan yang dialami jika perangsan sudah tidak ada, jika proses pengamatan sudah berhenti, dan hanya tinggal kesan-kesan saja. Tanggapan ialah gambaran ingatan dari pengamatan (Kartono, 1990). Untuk mengetahui respon masyarakat dapat dilihat melalui persepsi, sikap, dan partisipasi. Respon pada prosesnya didahului sikap seseorang, karena sikap merupakan kecenderungan atau kesediaan seseorang untuk bertingkahlaku kalau ia menghadapi suatu ransangan tertentu.

Menurut Soekanto (1993: 48) respon sebagai perilaku merupakan konsekuensi dari perilaku yang sebelumnya sebagai tanggapan atau jawaban suatu persoalan atau masalah tertentu. Menurut paradigma definisi sosial Weber (dalam Ritzen, 2003: 76) tentang tindakan sosial, respon adalah tindakan yang penuh arti dari individu sepanjang tindakan itu memiliki makna subjektif bagi dirinya dan diarahkan pada orang lain. Tindakan sosial yang dimaksud dapat berupa tindakan yang bersifat membatin atau bersifat subjektif yang mungkin terjadi karena terpengaruh dari situasi atau juga dapat merupakan tindakan pengulangan dengan sengaja sebagai akibat dari pengaruh situasi serupa. Abidin (dalam Susanto, 1997: 51-57) memberikan pengertian respon adalah reaksi yang dilakukan seseorang terhadap rangsangan, atau perilaku yang dihadirkan rangsangan.

Respon muncul pada diri manusia melalui suatu reaksi dengan urutan yaitu: sementara, ragu-ragu, dan hati-hati yang dikenal dengan trial response, kemudian respon akan terpelihara jika organisme merasakan manfaat dari rangsangan yang datang. Susanto (1988: 73) mengatakan respon merupakan reaksi, artinya penerimaan atau penolakan, serta sikap terhadap apa yang disampaikan oleh komunikator dalam pesannya. Respon dapat dibedakan menjadi opini (pendapat) dan sikap, dimana pendapat atau opini adalah jawaban terbuka (overt response) terhadap suatu persoalan yang dinyatakan dengan kata-kata yang diucapkan atau tertulis. Sedangkan sikap merupakan reaksi yang tertutup (convert 
response) yang bersifat emosional dan pribadi, merupakan tendensi untuk memberikan reaksi yang sangat positif atau negatif terhadap orang-orang, obyek, atau situasi tertentu.

Harvey dan Smith (dalam Ahmadi, 1999: 164) mendefinisikan bahwa respon merupakan bentuk kesiapan dalam menentukan sikap baik dalam arti positif atau negatif terhadap obyek atau situasi.

Respon juga diartikan suatu tingkahlaku atau sikap yang berwujud baik sebelum pemahaman yang mendetail, penilaian, pengaruh atau penolakan, suka atau tidak serta pemanfaatan pada suatu fenomena tertentu. Menurut Louis Thursone, respon merupakan jumlah kecenderungan dan perasaan, kecurigaan dan prasangka, pemahaman yang mendetail, ide-ide, rasa takut, ancaman dan keyakinan tentang suatu hal yang khusus. Pengertian tersebut dapat diketahui bahwa cara pengungkapan sikap dapat melalui pengaruh atau penolakan, penilaian, suka atau tidak suka, kepositifan atau kenegatifan suatu objek.

\section{Praktik Pengalaman Lapangan}

Menurut Kamus Besar Bahasa Indonesia (2005:892) praktik adalah pelaksanaan secara nyata apa yang disebut dalam teori. Sedangkan menurut Komaruddin (2006:200) "Praktik merupakan cara melaksanakan dalam keadaan nyata apa yang dikemukakan dalam teori". Dari definisi tersebut dapat kita lihat bahwa praktik merupakan suatu pelaksanaan dari teori dalam keadaan nyata. Praktik Pengalaman Lapangan (PPL) dilaksanakan oleh mahasiswa yang mencakup, baik latihan mengajar maupun tugas-tugas kependidikan di luar mengajar secara terbimbing dan terpadu untuk memenuhi persyaratan pembentukan profesi kependidikan. Pengalaman lapangan beroreintasi pada: (1) berorientasi pada kompetensi; (2) terarah pada pembentukan kemampuan-kemampuan profesional siswa calon guru atau tenaga kependidikan lainnya; (3) dilaksanakan, dikelola dan ditata secara terbimbing dan terpadu (Hamalik 2009:171).

Praktik Pengalaman Lapangan (PPL) adalah serangkaian kegiatan yang diprogramkan bagi mahasiswa LPTK, yang meliputi baik latihan mengajar maupun latihan di luar mengajar. Kegiatan ini merupakan ajang untuk membentuk dan membina kompetensi-kompetensi profesional yang disyaratkan oleh pekerjaan guru atau lembaga kependidikan lainnya. Sasaran yang ingin dicapai adalah kepribadian calon pendidik yang memiliki seperangkat pengetahuan, keterampilan, nilai dan sikap, serta pola tingkah laku yang diperlukan bagi profesinya serta cakap dan tepat menggunakannya di dalam menyelenggarakan pendidikan dan pengajaran, baik di sekolah maupun di luar sekolah (Hamalik, 2009:171-172).

Praktik Pengalaman Lapangan (PPL) merupakan salah satu mata kuliah keahlian mahasiswa Jurusan Pendidikan Agama Islam Fakultas Tarbiyah dan Keguruan UIN Alauddin Makassar. Mata kuliah ini dirancang guna membentuk pengalaman pertama mahasiswa menjadi guru di sekolah atau madrasah. Praktik Pengalaman Lapangan (PPL) pada Jurusan Pendidikan Agama Islam Fakultas Tarbiyah dan Keguruan UIN Alauddin dilaksanakan berbasis kolaboratif antara mahasiswa dengan guru pamong. Kolaboratifnya 
dapat dilalui melalui berbagai tahapan, yakni tahapan petama, guru pamong mengajar sedangkan mahasiswa PPL mencatat seluruh aktivitas pembelajaran (100\% peran guru pamong); tahapan kedua, guru pamong mengajar sedangkan mahasiswa PPL membantu guru pamong mendistribusi logistik pembelajaran (75\% peran guru pamong dan $25 \%$ peran mahasiswa PPL); tahapan ketiga, guru pamong mengajar dan mahasiswa PPL mengajar (50\% peran guru pamong dan 50\% peran mahasiswa PPL); tahapan keempat, mahasiswa PPL mengajar dan guru pamong membantu mahasiswa membagi logistik pembelajaran (75\% peran mahasiswa PPL dan guru pamong $25 \%$ ); tahapan kelima, mahasiswa melakukan pembelajaran mandiri (guru pamong mengamati aktivitas pembelajaran dan dosen pembimbing ikut melakukan proses pengamatan) yang dilanjutkan dengan FGD dalam rangka refleksi (Tim Penyusun Panduan PPL, 2017).

Praktik pengalaman lapangan kolaboratif antara mahasiswa praktikan dengan guru pamong yang dilaksanakan Fakultas Tarbiyah dan Keguruan UIN Alauddin Makassar, sesungguhnya mengadopsi teori pembelajaran sosial yang merupakan perluasan dari teori belajar perilaku yang tradisional (behavioristik). Teori pembelajaran sosial ini dikembangkan oleh Albert Bandura (1999). Teori ini menekankan bahwa lingkungan yang dihadapkan pada seseorang secara kebetulan, lingkungan-lingkungan itu kerap kali dipilih dan diubah oleh orang itu melalui perilakunya sendiri. Menurut Bandura, sebagaimana dikutip oleh (Kardi S dan Nur, 2000: 14) bahwa sebagian besar manusia belajar melalui pengamatan secara selektif dan mengingat tingkah laku orang lain. Inti dari pembelajaran sosial adalah pemodelan (modelling), dan pemodelan ini merupakan salah satu langkah paling penting dalam kegiatan pembelajaran.

Ada dua jenis pembelajaran melalui pengamatan, yaitu: (1) pembelajaran melalui pengamatan dapat terjadi melalui kondisi yang dialami orang lain, Contohnya seorang pelajar melihat temannya dipuji dan ditegur oleh gurunya karena perbuatannya, maka ia kemudian meniru melakukan perbuatan lain yang tujuannya sama ingin dipuji oleh gurunya. Kejadian ini merupakan contoh dari penguatan melalui pujian yang dialami orang lain; (2) pembelajaran melalui pengamatan meniru perilaku model meskipun model itu tidak mendapatkan penguatan positif atau penguatan negatif saat mengamati itu sedang memperhatikan model itu mendemonstrasikan sesuatu yang ingin dipelajari oleh pengamat tersebut dan mengharapkan mendapat pujian atau penguatan apabila menguasai secara tuntas apa yang dipelajari itu. Model tidak harus diperagakan oleh seseorang secara langsung, tetapi kita dapat juga menggunakan seseorang pemeran atau visualisasi tiruan sebagai model (Nur, 1998: 4).

Di samping teori Bandura, model PPL kolaboratif juga mengadopsi teori Dewey tentang pendidikan adalah, yakni "... pembentukan kembali arau pengorganisasian ulang pengalaman yang menambah maknanya dan yang menambah kemampuan si pelajar dalam memberi arah terhadap pengalaman yang selajutnya. Untuk mencapai maksud tersebut, guru memiliki peranan penting untuk membimbing pelajar memperluas pengetahuan dan 
kemampuan berpikirnya dalam menjelajah hubungan baru yang dibangunnya di atas pengetahuan yang dimiiliki sebelumnya.

Edgar Dale dengan Kerucut Pengalaman mendeskripsikan keterkaitan antara teori belajar dengan komunikasi audiovisual melalui Gambar 1 sebagai berikut:

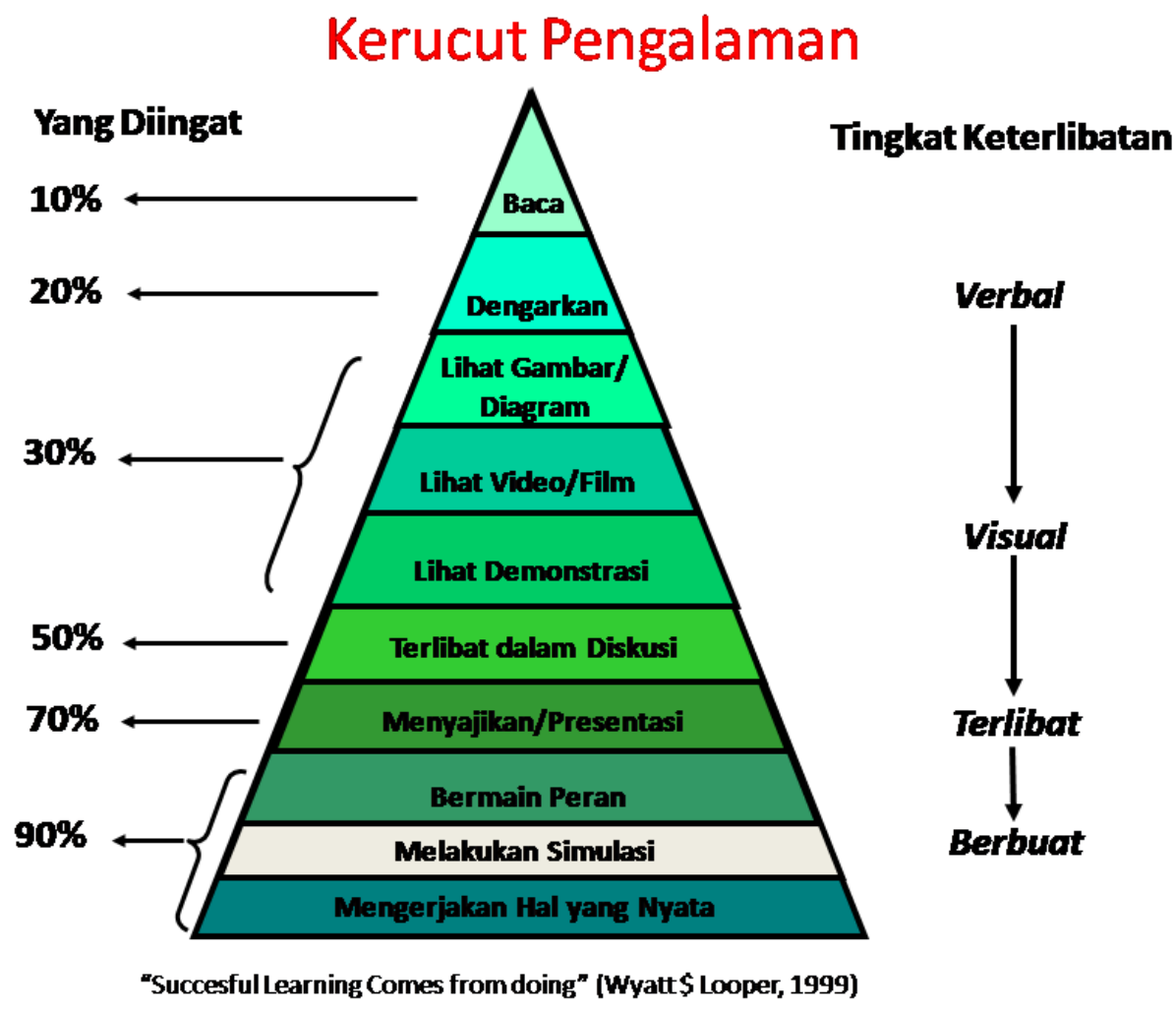

Gambar 1. Edgar Dale tentang Kerucut Pengalaman (Cone of Experience)

Pemikiran Edgar Dale tentang Kerucut Pengalaman (Cone of Experience) ini merupakan upaya awal untuk memberikan alasan atau dasar tentang keterkaitan antara teori belajar dengan komunikasi audiovisual. Kerucut Pengalaman Dale telah menyatukan teori pendidikan John Dewey (salah satu tokoh aliran progresivisme) dengan gagasangagasan dalam bidang psikologi yang tengah populer pada masa itu.

Perubahan ini (PPL berbasis kolaboratif) dilakukan dalam rangka perbaikan proses pelaksanaan praktik pengalaman lapangan guna membentuk watak mahasiswa Fakultas Tarbiyah dan Keguruan UIN Alauddin Makassar menjadi guru pemula yang belajar menjadi guru di madrasah/sekolah. Perubahan ini juga dimaksudkan untuk meminimalisir kerugian yang dimiliki peserta didik jika dia diajar oleh bukan guru professional, sementara mahasiswa praktikan (PPL) ini merupakan calon pendidik yang jika kelak mengikuti program PPG dalam waktu setahun lamanya untuk menjadi guru professional melalui LPTK.

Sebelumnya, PPL dilaksanakan langsung secara mandiri di kelas oleh mahasiswa tanpa diamati oleh dosen pembimbing. Bahkan, kadangkala juga guru pamong begitu 
besar harapannya kepada mahasiswa PPL sehingga mereka (mahasiswa) PPL tanpa didampingi di kelas. Akhirnya, praktik semacam ini dipandang sangat merugikan peserta didik dan juga merugikan mahasiswa PPL, karena tidak mengetahui kelebihan an kekurangan pelaksanaan pembelajaran yang dikelolanya.

Secara khusus, Jurusan Pendidikan Agama Islam Fakultas Tarbiyah dan Keguruan UIN Alauddin Makassar merupakan bahagian dari pola perubahan PPL ini. Tahun 2018 nanti, mahasiswa Jurusan Pendidikan Agama Islam Fakultas Tarbiyah dan Keguruan UIN Alauddin Makassar melaksanakan PPL berbasis kolaboratif berjumlah 177 orang yang tentunya berpraktik pada sejumlah madrasah dan sekolah yang ada di wilayah Kabupaten Gowa dan Sulawesi Selatan. Dua wilayah ini, merupakan wilayah kerjasama fakultas dan secara khusus Jurusan Pendidikan Agama Islam Fakultas Tarbiyah dan Keguruan UIN Alauddin Makassar.

Dengan melihat pola perubahan pelaksanaan PPL sebagaimana digambarkan di atas, maka dipandang perlu diketahui dalam bentuk respon bagi seluruh komponen yang terlibat dalam kegiatan PPL. Upaya mengetahuinya tentu melalui kegiatan penelitian, yang diharapkan mampu mendeskripsikan secara rasional, empirik dan sistematis mengenai pelaksanaan PPL berbasis kolaboratif. Program PPL ini sudah berjalan di tahun 2017 ini, secara teori program yang telah berjalan minimal setahun, maka program itu perlu diuji apakah memiliki manfaat yang signifikan atau tidak guna peningkatan mutu pelaksanaan sebuah program.

\section{Tujuan}

Tujuan penelitian ini adalah untuk mendeskripsikan: (1) pelaksanaan prakik pengalaman lapangan berbasis kolaboratif antara mahasiswa dengan guru pamong di MTsN 1 Kabupaten Gowa; (2) respon mahasiswa terhadap pelaksanaan prakik pengalaman lapangan berbasis kolaboratif di MTsN 1 Kabupaten Gowa; dan (3) respon guru pamong terhadap pelaksanaan prakik pengalaman lapangan berbasis kolaboratif di MTsN 1 Kabupaten Gowa.

\section{METODE PENELITIAN}

Penelitian ini merupakan jenis penelitian kuantitatif yang berupaya menggambarkan respon mahasiswa dan guru pamong mengenai PPL berbasis kolaboratif di MTsN Kabupaten Gowa. Populasi penelitian ini adalah seluruh mahasiswa Jurusan Pendidikan Agama Islam Fakultas Tarbiyah dan Keguruan UIN Alauddin Makassar yang ber-PPL di MTsN Kabupaten Gowa (18 orang mahasiswa dengan 3 kelompok guru pamong), dan guru pamong yang ditunjuk melalui Keputusan Dekan Fakultas Tarbiyah dan Keguruan UIN Alauddin Makassar Nomor 1744 Tahun 2018 (khusus untuk mahasiswa Jurusan PAI ada 3 guru pamong di MTsN Kabupaten Gowa).

Metode pengumpulan data yang digunakan dalam penelitian ini adalah angket, dengan instrumen berupa daftar pertanyaan yang diberikan kepada para responden untuk dijawab berdasarkan keadaan yang sesungguhnya. Angket yang dimaksud terdiri respon 
mahasiswa dan guru pamong mengenai pelaksanaan PPL berbasis kolaboratif di MTsN Kabupaten Gowa.

Angket dimaksud terkait lima tahapan pelaksanaan PPL berbasis kolaboratif, yakni: (1) pelaksanaan pembekalan; (2) kegiatan observasi mahasiswa; (3) penyusunan perangkat pembelajaran; (4) kegiatan pembelajaran; dan (5) pembuatan laporan kegiatan. Angket ini terdiri dari 65 item pernyataan baik untuk mahasiswa PPL maupun dan guru pamong. Pilihan jawaban instrumen penelitian ini, yakni: 4= Sangat Sesuai; 3= Sesuai; 2= Kurang Sesuai; dan 1= Tidak Sesuai.

Teknik analisis data yang digunakan dalam penelitian ini adalah analisis statistik deskriptif dengan mencari nilai rerata berdasarkan respon guru pamong dan mahasiswa PPL. Setelah itu, ditarik kesimpulan berdasarkan kriteria:

$$
\begin{array}{ll}
3,5 \leq \mathrm{R} \leq 4 & =\text { Sangat Baik } \\
2,5 \leq \mathrm{R}<3,5 & =\text { Baik } \\
1,5 \leq \mathrm{R}<2,5 & =\text { Kurang Baik } \\
\mathrm{R}<1,5 & =\text { Tidak Baik }
\end{array}
$$

Keterangan: $R=$ Respon dengan maksud respon mahasiswa dan guru pamong.

Respon tersebut kemudian diklasifikasi berdasarkan kategori respon sebagai berikut: positif $(2,01-4,0)$ dan negatif $(0-2,00)$.

\section{HASIL DAN PEMBAHASAN PENELITIAN}

\section{A. Pelaksanaan Prakik Pengalaman Lapangan berbasis Kolaboratif antara Mahasiswa dengan Guru Pamong di MTsN Kabupaten Gowa}

Pelaksanaan Praktik Pengalaman Lapangan berbasis Kolaboratif antara Mahasiswa dengan Guru Pamong di MTsN Kabupaten Gowa dapat dilihat melalui berbagai tahapan kegiatan, secara garis besarnya: (a) pendaftaran dan seleksi melalui akademik fakultas; (b) kegiatan pembekalan mahasiswa; (c) workshop dosen pembimbing dan guru pamong; (d) pelepasan dan pengantaran mahasiswa PPL; (e) observasi sekolah dan perencanaan program; (f) mengajar terbimbing pola 75:25; (g) FGD 1; (h) pelaksanaan pembelajaran terbimbing pola 50:50; (i) FGD 2; (j) mengajar mandiri; (k) FGD 3; (l) ujian praktik; (m) penarikan mahasiswa; dan (n) penyusunan laporan (Hasil olah data deskripsi pelaksanaan PPL kolaboratif di MTsN Kab. Gowa).

\section{B. Respon Mahasiswa terhadap Pelaksanaan Prakik Pengalaman Lapangan berbasis Kolaboratif di MTsN 1 Kabupaten Gowa.}

Respon mahasiswa terhadap pelaksanaan parktik pengalaman lapangan kolaboratif di MTsN 1 Kabupaten Gowa, secara garis besarnya dapat dilihat melalui 5 tahapan kegiatan, yakni kegiatan pembekalan, kegiatan observasi, keterlibatan dalam pembimbingan penyusunan perangkat pembelajaran, kegiatan pembelajaran, dan 
pembimbingan dalam pembuatan laporan kegiatan. Respon mahasiswa dapat dilihat melalui Tabel 1 sebagai berikut:

Tabel 1. Respon Mahasiswa terhadap Pelaksanaan PPL Kolaboratif

\begin{tabular}{lr}
\hline \multicolumn{2}{c}{ Columnl } \\
\hline Mean & 2.993162 \\
Standard Error & 0.069953 \\
Median & 3.069231 \\
Mode & 3.338462 \\
Standard & \\
Deviation & 0.296785 \\
Sample & \\
Variance & 0.088081 \\
Kurtosis & -0.90933 \\
Skewness & -0.62599 \\
Range & 0.938462 \\
Minimum & 2.4 \\
Maximum & 3.338462 \\
Sum & 53.87692 \\
Count & 18 \\
\hline
\end{tabular}

Tabel 1 di atas menggambarkan bahwa nilai rerata respon mahasiswa 2.99. Nilai ini jika dikonfirmasi pada kajian metode penelitian berada dalam kategori baik dengan respon positif. Dengan demikian, dapat dipahami bahwa: (1) seluruh tahapan pelaksanaan PPL kolaboratif telah berjalan sesuai yang diharapkan; dan (2) Pelaksanaan PPL kolaboratif ini telah mendapatkan respon positif dari mahasiswa sebagai praktikan di MTsN Kabupaten Gowa.

\section{Respon Guru Pamong terhadap Pelaksanaan Prakik Pengalaman Lapangan berbasis Kolaboratif di MTsN Kabupaten Gowa.}

Respon guru pamong terhadap pelaksanaan PPL kolaboratif di MTsN Kabupaten Gowa, secara garis besarnya dapat dilihat melalui 5 tahapan kegiatan, yakni workshop dosen pembimbing dan guru pamong, kegiatan observasi, penyusunan perangkat pembelajaran, kegiatan pembelajaran, dan pembuatan laporan kegiatan. Respon guru pamong dapat dilihat melalui Tabel 2 sebagai berikut:

Tabel 2. Respon Guru Pamong terhadap Pelaksanaan PPL Kolaboratif

\begin{tabular}{ll}
\hline \multicolumn{2}{c}{ Columnl } \\
\hline & 3.047619 \\
Mean & 0.011905
\end{tabular}




\begin{tabular}{lr} 
Median & 3.035714 \\
Mode & 3.035714 \\
Standard \\
Deviation \\
Sample & 0.02062 \\
Variance & 0.000425 \\
Kurtosis & \#DIV/0! \\
Skewness & 1.732051 \\
Range & 0.035714 \\
Minimum & 3.035714 \\
Maximum & 3.071429 \\
Sum & 9.142857 \\
Count & 3 \\
\hline
\end{tabular}

Tabel 2 di atas menggambarkan bahwa nilai rerata respon guru pamong 3.04. Nilai ini jika dikonfirmasi pada kajian metode penelitian berada dalam kategori baik dengan respon positif. Dengan demikian, dapat dipahami bahwa: (1) seluruh tahapan pelaksanaan PPL kolaboratif telah berjalan sesuai yang diharapkan; dan (2) Pelaksanaan PPL kolaboratif ini telah mendapatkan respon positif dari guru pamong sebagai pendamping praktik pengalaman lapangan di MTsN Kabupaten Gowa.

\section{KESIMPULAN}

1. Pelaksanaan Prakik Pengalaman Lapangan berbasis Kolaboratif antara Mahasiswa dengan Guru Pamong di MTsN Kabupaten Gowa telah berjalan dengan baik dengan tahapan kegiatan: pendaftaran dan seleksi melalui akademik fakultas; (b) kegiatan pembekalan mahasiswa; (c) workshop dosen pembimbing dan guru pamong; (d) pelepasan dan pengantaran mahasiswa PPL; (e) observasi sekolah dan perencanaan program; (f) mengajar terbimbing pola 75:25; (h) FGD 1; (i) pelaksanaan pembelajaran terbimbing pola 50:50; (j) FGD 2; (k) mengajar mandiri; (l) FGD 3; (m) ujian praktik; (n) penarikan mahasiswa; dan (o) penyusunan laporan.

2. Respon mahasiswa terhadap pelaksanaan praktik pengalaman lapangan berbasis kolaboratif antara guru pamong di MTsN 1 Kabupaten Gowa termasuk dalam kategori positif, yakni nilai rerata 2.99 (baik).

3. Respon guru pamong terhadap pelaksanaan praktik pengalaman lapangan berbasis kolaboratif antara guru pamong di MTsN Kabupaten Gowa termasuk dalam kategori positif, yakni nilai rerata 3.04 (baik). 


\section{DAFTAR PUSTAKA}

Ahmadi, Abu. Psikologi Sosisal. Jakarta: Rineka Cipta, 1999.

Alauddin, Fakultas Tarbiyah dan Keguruan UIN Alauddin Makassar, Pedoman Praktik Pengalaman Lapangan, 2017.

Dale, Edgar, 1969. Audio Visual Methods in Teaching, New Yorg: Holt, Rinehart and Winston Inc. The Dryden Press.

Depdiknas. 2005. Kamus Besar Bahasa Indonesia. Pradya Paramitha. Jakarta.

Dewey, John. Dcmocracy and Education. Nerv York: Macmillan, 1964.

Hamalik, Oemar. Proses Belajar Mengajar. Bandung: Bumi Aksara. 2009.

Kardi S. dan Nur M., 1997. Pengajaran Langsung. Surabaya: Unesa.

Nur, M. 1988. Proses Belajar Mengajar dengan Metode Pendekatan Keterampilan Proses. Surabaya, SIC, 1998.

Ritzen, George - Douglas J. Goodman, 2007. Teori-Sosiologi Kontemporer, Jakarta, Kencana Lenada Media Group.

Soekanto, Soerjono. 1993. Sosiologi suatu Pengantar. Jakarta: Raja Grafindo.

Susanto, Astrid. S. 1997. Pengantar Sosiologi dan Perubahan Sosial. Bina Cipta. Jakarta. 